\title{
Sensitivity of point-of-care IgM and lgG test in critically ill patients with SARS-Cov-2
}

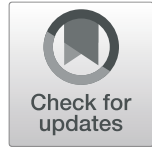

\author{
Lee S. Nguyen ${ }^{1,2^{*}}$ (D) Driss Laghlam² ${ }^{2}$ Emmanuelle De Gonfreville ${ }^{1}$, Frédéric Pène ${ }^{1}$, Flore Rozenberg ${ }^{3}$ and \\ Jean-Paul Mira ${ }^{1}$
}

\section{Dear Editor,}

The severe acute respiratory syndrome coronavirus 2 (SARS-Cov-2) pandemic requires accurate diagnostic tests to triage patients between properly isolated and regular wards [1]. Gold-standard tests are based on reversetranscriptase polymerase chain reaction (RT-PCR) performed on nasopharyngeal swabs [2]. Quick serology tests detecting immunoglobulin $\mathrm{M}$ and $\mathrm{G}$ (respectively IgM and IgG) targeted against SARS-Cov-2 are also available $[3,4]$; however, concerns have been raised on their sensitivity in intensive care units (ICU), where patients are more severe and some immunosuppressed.

In this multicenter observational study, we assessed sensitivity of a point-of-care serology test (POCST) regarding SARS-Cov-2, in ICU patients presenting severe SARSCov-2 infection. All included patients were positive for SARS-Cov-2 using routine RT-PCR methodology. POCST was sampled with finger prick, with $10 \mu \mathrm{L}$ of blood and tested with the device, BIOSYNEX COVID-19 BSS (IgG/ $\operatorname{IgM})^{\circ}$ (Biosynex, Illkirch-Graffenstaden, France). Each POCST incorporated a quality control. Concordance between RT-PCR and POCST was assessed regarding the presence of IgM and/or IgG. Patients for whom POCST showed no IgM and no IgG were considered negative. The study was approved by institutional review board (00012608-2020-01) and registered under clinicaltrials.gov identifier NCT04467008.

Overall, 99 patients were included. Patients were $62.4 \pm 13.3$ years old, $34.7 \%$ were women, and average

\footnotetext{
* Correspondence: nguyen.lee@icloud.com

${ }^{1}$ Intensive Care Medicine Department, AP.HP.Centre Cochin University

Hospital, Paris, France

${ }^{2}$ Intensive Care Medicine Department, CMC Ambroise Paré, Neuilly-sur-Seine, France

Full list of author information is available at the end of the article
}

body-mass index (BMI) was $29.1 \pm 5.9 \mathrm{~kg} / \mathrm{m}^{2}$. Mean Simplified Acute Physiological Score II (SAPS II) was $50.1 \pm$ 22.8. Average delay between POCST and first symptoms was $17.9 \pm 9.1$ days (see baseline characteristics in Table 1). Results were obtained in less than $10 \mathrm{~min}$ for all, except in $2(2.0 \%)$ in whom quality control was not met; hence, tests required to be performed twice.

The POCST yielded 8 (8.1\%) negatives, corresponding to a sensitivity of $91.9 \%$. Delay between first symptoms and POCST was significantly lower in negative than positive patients $(10.4 \pm 7.8$ vs $18.6 \pm 7.9$ days, $p=0.005)$ (see Fig. 1 a). Negatives were significantly younger (50.7 \pm 16.9 vs. $63.5 \pm 12.5$ years old, $p=0.009$ ). Rest of variables were similar, including lymphocytes' count $(1.0 \pm 0.7$ vs $2.4 \pm 8.5 \mathrm{G} / \mathrm{L}, p=0.55)$ (see Table 1 and Fig. 1). Multivariable logistic regression showed that both delay and age were independently associated with negative POCST (respectively adjusted odds-ratio, 0.82 $(0.71-0.95)$ per 1 -day increase, $p$ value $=0.009$, and 0.93 $(0.87-0.98)$ per 1 -year increase, $p$ value $=0.013)$.

The other three different serology profiles were IgM+l IgG - in 7, IgM+/IgG+ in 64, and IgM-/IgG+ in 19 patients. Delay between first symptoms and POCST was significantly different across all four groups. Contrary to SAPS II, distribution of age, BMI, and lymphocytes' count did not significantly differ across all four groups (see Fig. 1b-d).

In this observational study in ICU patients, sensitivity of POCST was similar to specifications provided by the manufacturer (93\%). Variables associated with negative results were age and delay between onset and POCST which was expected given known dynamics of immunization after SARS-Cov-2 infection [5]. Neither patients' severity nor immunosuppression status modified risk of presenting negative POCST results. Lymphocytes' count was not significantly different, however; it 
Table 1 Study cohort baseline characteristics (all patients had confirmed COVID-19 pneumonia)

\begin{tabular}{lllll}
\hline & Overall $(\boldsymbol{n}=\mathbf{9 9})$ & Positives $(\boldsymbol{n}=\mathbf{9 1})$ & Negatives $(\boldsymbol{n}=\mathbf{8})$ & $\begin{array}{l}\text { Intergroup } \\
\text { comparison } \boldsymbol{p} \text { value }\end{array}$ \\
\hline Age (years) & & & $50.7 \pm 16.9$ & $0.009^{\ddagger}$ \\
Woman patient & $34(34.3 \%)$ & $32(35.2 \%)$ & $2(25.0 \%)$ & $0.71^{\Phi}$ \\
Body-mass index (kg/m $\left.{ }^{\mp}\right)$ & $29.1 \pm 5.9$ & $29.2 \pm 5.8$ & $29.1 \pm 7.1$ & $0.94^{\mathrm{M}}$ \\
Delay between first symptoms and POCST (days) & $17.9 \pm 8.2$ & $18.6 \pm 7.9$ & $10.4 \pm 7.8$ & $0.006^{\ddagger}$ \\
Chronic immunosuppression & $9(9.1 \%)$ & $7(7.7 \%)$ & $2(25.0 \%)$ & $0.15^{\Phi}$ \\
Diabetes & $31(31.3 \%)$ & $28(30.8 \%)$ & $3(37.5 \%)$ & $0.70^{\Phi}$ \\
Corticosteroid use in the past 14 days & $18(18.2 \%)$ & $16(17.6 \%)$ & $2(25.0 \%)$ & $0.63^{\Phi}$ \\
Immunosuppression in the past 14 days & $5(5.1 \%)$ & $5(5.5 \%)$ & $0(0.0 \%)$ & $1.0^{\Phi}$ \\
SAPS II at admission & $50.1 \pm 23.0$ & $51.1 \pm 22.4$ & $40.4 \pm 28.7$ & $0.17^{\mathrm{M}}$ \\
Creatininemia at admission ( $\mu$ mol/L) & $106.4 \pm 123.7$ & $106.4 \pm 128.6$ & $107.3 \pm 45.8$ & $0.047^{\mathrm{M}}$ \\
Lymphocytes' count on day of POCST (G/L) & $2.3 \pm 8.2$ & $2.4 \pm 8.5$ & $1.0 \pm 0.7$ & $0.56^{\mathrm{M}}$ \\
Fibrinogen on day of POCST (g/L) & $5.8 \pm 2.8$ & $5.8 \pm 2.8$ & $4.4 \pm 1.2$ & $0.11^{\mathrm{M}}$
\end{tabular}

Chronic immunosuppression denotes either human immunodeficiency virus, solid organ transplantation or allogeneic hematopoietic stem cell transplantation POCST point-of-care serology test, SAPS II Simplified Acute Physiological Score II

${ }^{M}$ Mann-Whitney $U$ test for distribution

"Student's $t$ test

${ }^{\oplus}$ Fischer's exact test 


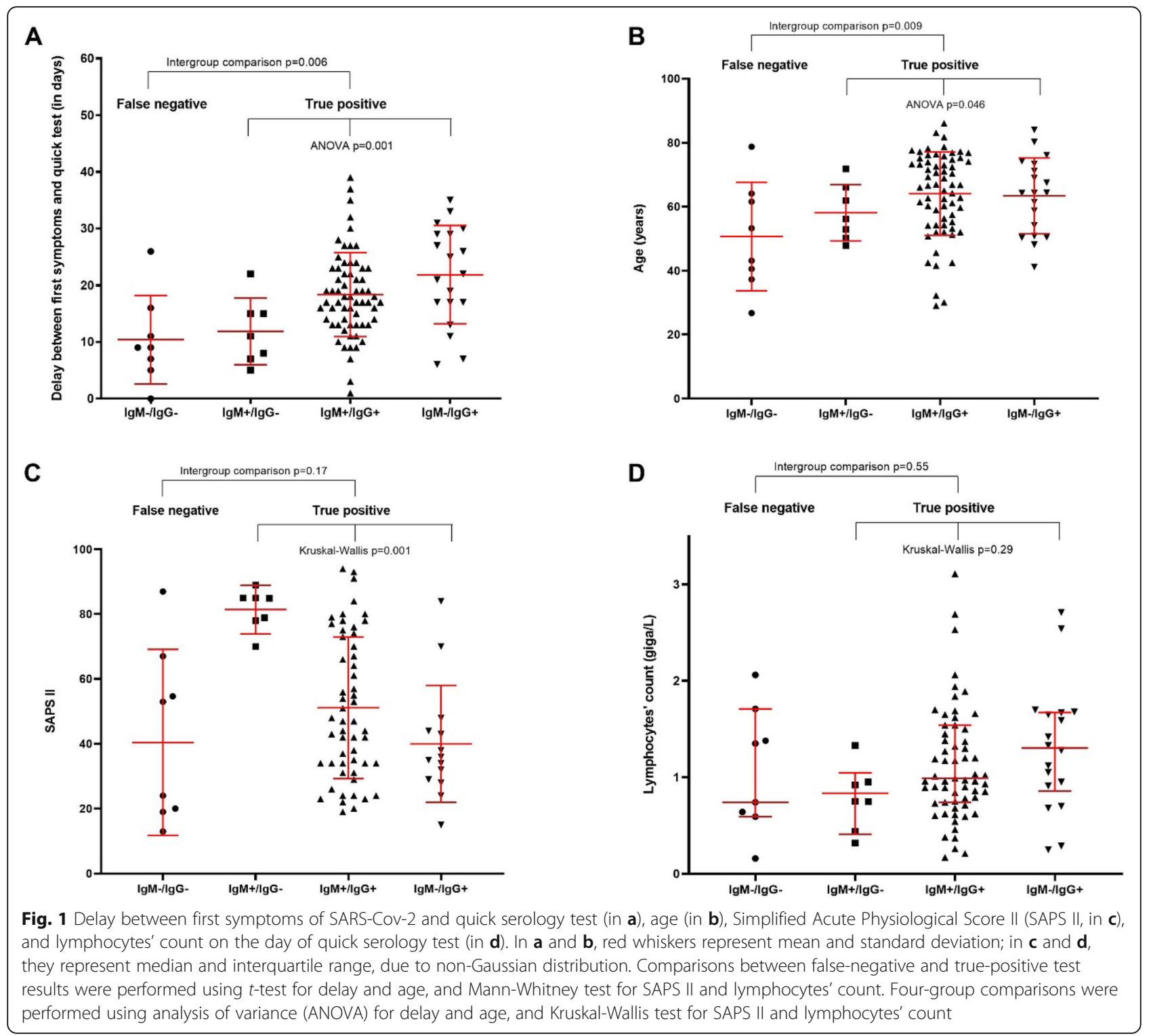

was twice as lower in false-negative patients although a lack of power be incriminated.

Although multicenter, this study suffers from small sample size, hence validation in larger cohorts aiming at assessing effects of POCST on in-hospital virus contamination and beds management may answer whether these quick diagnostic tests alleviate burden of SARSCov-2 on ICU beds and staff [6].

To conclude, we assessed diagnostic performance of a point-of-care serology test for SARS-CoV-2 in 99 patients hospitalized in ICU with a definite SARS-Cov-2 and found a $91.9 \%$ sensitivity, confounded by younger age and shorter delay since symptoms onset. POCST sensitivity was not considered elevated enough in clinical practice to help triage between SARS-CoV-2 isolated wards and regular ICU wards.
Acknowledgements

We particularly thank Dr. Julien Charpentier, Prof. Alain Cariou, and Prof. Jean-Daniel Chiche, from Cochin university hospital, ICU department, and Dr. Pierre Squara, Dr. Philippe Estagnasie, and Dr. Alain Brusset from CMC Ambroise Paré, ICU department for their participation. We also thank Mr. Charles Jouars and Mr. Sofiane Sifi for their contribution. We thank all physicians who participated to patients screening. Finally, we thank Biosynex which freely provided point-of-care serology tests.

\section{Authors' contributions}

LSN designed the study, participated to data collection, wrote the manuscript and performed statistical analyses. DL, EDG, FR, JDC and JPM participated to data collection and provided critical reviewing to the manuscript. The authors read and approved the final manuscript.

Funding

None.

Availability of data and materials

The datasets used and/or analyzed during the current study are available from the corresponding author on reasonable request. 


\section{Ethics approval and consent to participate}

Study was approved by institutional review board (00012608-2020-01) and registered on clinicaltrials.gov (identifier NCT04467008). Patients and/or next of kin were reached for consent.

\section{Consent for publication}

All authors consent for publication.

\section{Competing interests}

All authors declare no conflict of interest regarding the content of this work. In particular, none has interests with BioSynex.

\section{Author details}

${ }^{1}$ Intensive Care Medicine Department, AP.HP.Centre Cochin University Hospital, Paris, France. ${ }^{2}$ Intensive Care Medicine Department, CMC Ambroise Paré, Neuilly-sur-Seine, France. ${ }^{3}$ Virology Department, AP.HP.Centre Cochin University Hospital, Paris, France.

Received: 10 August 2020 Accepted: 14 September 2020

Published online: 24 September 2020

\section{References}

1. Yong SEF, Anderson DE, Wei WE, et al. Connecting clusters of COVID-19: an epidemiological and serological investigation. Lancet Infect Dis. 2020;20(7): 809-15. https://doi.org/10.1016/S1473-3099(20)30273-5.

2. Woloshin S, Patel N, Kesselheim AS. False Negative Tests for SARS-CoV-2 Infection - Challenges and Implications. N Engl J Med. 2020;383(6):e38. https://doi.org/10.1056/NEJMp2015897.

3. Carter L, Garner LV, Smoot JW, Li Y, Zhou Q, Saveson CJ, Sasso JM, Gregg AC, Soares DJ, Beskid TR, et al. Assay techniques and test development for COVID-19 diagnosis. ACS Cen Sci. 2020;6(5):591-605.

4. Li Z, Yi Y, Luo X, et al. Development and clinical application of a rapid IgMIgG combined antibody test for SARS-CoV-2 infection diagnosis [published online ahead of print, 2020 Feb 27]. J Med Virol. 2020. https://doi.org/10. 1002/jmv.25727.

5. Sethuraman N, Jeremiah SS, Ryo A. Interpreting Diagnostic Tests for SARSCoV-2. JAMA. 2020:323(22):2249-51. https://doi.org/10.1001/jama.2020.8259.

6. Griffin KM, Karas MG, Ivascu NS, Lief L. Hospital preparedness for COVID-19: a practical guide from a critical care perspective. Am J Respir Crit Care Med. 2020;201(11):1337-44.

\section{Publisher's Note}

Springer Nature remains neutral with regard to jurisdictional claims in published maps and institutional affiliations.

Ready to submit your research? Choose BMC and benefit from:
- fast, convenient online submission
- thorough peer review by experienced researchers in your field
- rapid publication on acceptance
- support for research data, including large and complex data types
- gold Open Access which fosters wider collaboration and increased citations
- maximum visibility for your research: over 100M website views per year
At BMC, research is always in progress.
Learn more biomedcentral.com/submissions

